\title{
Protein(s) from the Gram-Positive Bacterium Clavibacter michiganensis subsp. michiganensis Induces a Hypersensitive Response in Plants
}

\author{
C. Alarcón, J. Castro, F. Muñoz, P. Arce-Johnson, and J. Delgado
}

Departamento de Genética Molecular y Microbiología, Facultad de Ciencias Biológicas, Pontificia Universidad Católica de Chile, Casilla 114-D, Santiago, Chile.

Accepted for publication 18 December 1997.

\begin{abstract}
Alarcón, C., Castro, J., Muñoz, F., Arce-Johnson, P., and Delgado, J. 1998. Protein(s) from the gram-positive bacterium Clavibacter michiganensis subsp. michiganensis induces a hypersensitive response in plants. Phytopathology 88:306-310.

The gram-positive tomato pathogen Clavibacter michiganensis subsp. michiganensis induced a local necrotic response on four-o'clock (Mirabilis jalapa) and tobacco (Nicotiana tabacum) plants. This necrosis response was characteristic of the hypersensitive response (HR). The cell-free cul-

ture supernatant from strain CMM623 also induced a necrosis that was phenotypically similar to that induced by the bacteria. Inhibitors of plant metabolism suppressed the necrotic reaction of both $M$. jalapa and tobacco. The HR-inducing activity present in the supernatant was heat stable, sensitive to proteases, and had an apparent molecular mass in the range of 35 to $50 \mathrm{kDa}$ as determined by sodium dodecyl sulfate-polyacrylamide gel electrophoresis. The properties observed for the necrosis-inducing activity resembled harpin and PopA described from gram-negative phytopathogenic bacteria.
\end{abstract}

Gene-for-gene interactions are a widely occurring phenomenon in which single dominant alleles in plants and their pathogens determine whether the plant will be resistant or susceptible to attack (17). The major hypothesis to explain resistance proposes that a receptor present in the plant (encoded by $R$ genes) specifically recognizes a molecule called an elicitor, which is produced by an avr gene in the pathogen $(29,36,41)$. The resistant response is characterized by a hypersensitive response (HR) that is characterized by necrosis resulting from localized plant cell death at the site of infection $(13,21,29)$.

The elicitors of gram-negative bacteria are produced directly or indirectly by the $a v r$ gene product. An elicitor produced indirectly by an $a v r$ gene product is represented by the low molecular weight gamma-lactones called syringolides from Pseudomonas syringae pv. tomato (35). A race-specific elicitor produced directly by an avr gene product is represented by AvrBs3 from Xanthomonas campestris pv. vesicatora $(22,38)$ and AvrPto from P. syringae pv. tomato $(34,37)$. Avr proteins seem to be recognized by the $R$ gene product only inside the plant cell $(8,32)$.

In addition to avirulence genes, bacteria require hrp (hypersensitivity response and pathogenicity) genes to induce a HR in nonhost or resistant cultivars $(7,23)$. hrp gene products are also necessary to cause disease in compatible hosts (7). Most Hrp proteins appear to be involved in the assembly of a type III protein secretion pathway $(6,15,39)$ through which bacterial virulence factors, including avr gene products and harpins (described below), traverse to the extracellular milieu or are injected into host cells $(26,34,37,38,40)$. One of the hrp genes encodes a proteinaceous HR elicitor named harpin, which has been found in P. syringae (26), Erwinia amylovora (40), E. chrysanthemi (3), and recently in E. carotovora (11). Purified harpins are biologically active and, by themselves, can trigger a HR on a variety of different nonhost plants $(3,40)$. This

Corresponding author: J. Delgado; E-mail address: jdelgado@genes.bio.puc.cl

Publication no. P-1998-0203-01R

(c) 1998 The American Phytopathological Society plant defense response does not follow the gene-for-gene interaction $(24,41)$. Another bacterial protein elicitor of the HR with some structural characteristics of harpins, named PopA, has been isolated from cell-free culture supernatants (CFCS) of Ralstonia (formerly Pseudomonas) solanacearum (1).

Although HR induction is widespread in phytopathogenic gramnegative bacteria, it has been reported only in two cases for grampositive bacteria. In 1990, Gitaitis (20) described an apparent HR on four-o'clock (Mirabilis jalapa) and tobacco when the intercellular spaces of leaf panels were infiltrated with the tomato pathogen Clavibacter michiganensis subsp. michiganensis. Later, it was reported that the exopolysaccharide produced by this bacterium is not responsible for the necrosis induced on M. jalapa (4), suggesting that other molecules, which might include proteins, are involved in this effect. In the second case, Nissinen et al. (31) recently described a proteinaceous elicitor from CFCS of the potato pathogen $C$. michiganensis subsp. sepedonicus. This elicitor shares some harpin characteristics and induces HR only on tobacco.

In the current work, we described a proteinaceous HR-eliciting activity from the gram-positive phytopathogen $C$. michiganensis subsp. michiganensis, which elicits a HR on M. jalapa and tobacco plants.

\section{MATERIALS AND METHODS}

Bacterial strains and culture media. C. michiganensis subsp. michiganensis strain CMM623 was obtained from X. Besoaín, Universidad Católica de Valparaíso (this strain was isolated from Quillota, Chile) and CMM100, which is a plasmid-free derivative of NCPPB382 (30), was a gift from R. Eichenlaub, Universität Bielefeld, Germany. Strains were routinely grown at $26^{\circ} \mathrm{C}$ in M523 medium, which contains per liter $10 \mathrm{~g}$ of sucrose, $8 \mathrm{~g}$ of casein hydrolysate, $4 \mathrm{~g}$ of yeast extract, $2 \mathrm{~g}$ of $\mathrm{K}_{2} \mathrm{HPO}_{4}$, and $0.3 \mathrm{~g}$ of $\mathrm{MgSO}_{4} 7 \mathrm{H}_{2} \mathrm{O}$. The minimal medium used was a modification of the semiselective medium for $C$. michiganensis (SCM) (14) and contains per liter $0.25 \mathrm{~g}$ of $\mathrm{MgSO}_{4} 7 \mathrm{H}_{2} \mathrm{O}, 0.5 \mathrm{~g}$ of $\mathrm{KH}_{2} \mathrm{PO}_{4}, 2 \mathrm{~g}$ of $\mathrm{K}_{2} \mathrm{HPO}_{4}, 10 \mathrm{~g}$ of sucrose, and $0.1 \mathrm{~g}$ of yeast extract. 
Preparation of CFCS. Bacteria were grown for $48 \mathrm{~h}$ in yeast extract glucose $\mathrm{MgSO}_{4}$ (YGM) (12) or M523 medium. After centrifugation at $8,000 \times g$ for $15 \mathrm{~min}$ at $4{ }^{\circ} \mathrm{C}$, the culture supernatant was filtered through a $0.45-\mu \mathrm{m}$ ME25 membrane filter (Schleicher \& Schuell Inc., Keene, NH). Sterility of CFCS preparations was confirmed by culturing. After the addition of phenylmethylsulfonyl fluoride (PMSF) (0.5 mM final concentration), this preparation was immediately used either for infiltration assays on M. jalapa and tobacco plant leaves or for purification and characterization of the elicitor.

For preparation of the bacteria to be used in infiltration assays, overnight M523 cultures were washed, suspended in sterile water, and adjusted to appropriate cell concentrations by measuring optical density at $600 \mathrm{~nm}$.

Plant growth and inoculation procedures. $M$. jalapa plants were grown in soil from seed under greenhouse conditions with temperatures between 15 to $35^{\circ} \mathrm{C}$ for 2 to 3 weeks (two-leaf stage). Twenty-four hours before inoculation of bacteria or supernatants, plants were transferred to a growth chamber with a 16-h light/8-h dark photoperiod at $25^{\circ} \mathrm{C}$ and a light intensity of $100 \mu \mathrm{E} \mathrm{m}^{-2} \mathrm{~s}^{-1}$. Tobacco plants (Nicotiana tabacum L. var. Xanthi) were grown under similar conditions, and prior to inoculation, they were moved to a chamber at $20^{\circ} \mathrm{C}$.

Plants were infiltrated with $C$. michiganensis subsp. michiganensis or CFCS with a 1-ml needleless syringe through a small hole made in the plant leave with a surgical blade. Inoculated $M$. jalapa or tobacco were moved back to the growth chamber under the same conditions prior to inoculation and visually monitored for reactions.

Active plant metabolic inhibitors were infiltrated as described in He et al. (25). Briefly, cycloheximide, $\alpha$-amanitin, sodium vanadate, and lanthanum chloride were used at final concentrations of $70 \mu \mathrm{M}, 200 \mu \mathrm{M}, 50 \mu \mathrm{M}$, and $1 \mathrm{mM}$, respectively.

Heat and protease treatment of CFCS. CFCS contained in Eppendorf tubes were heated to $100^{\circ} \mathrm{C}$ in a boiling water bath for $10 \mathrm{~min}$.

The chemical nature of the necrosis-inducing activity was investigated by treatment of CFCS with different proteases. Pronase (Sigma Chemical Co., St. Louis) and proteinase K (Boehringer Mannheim Biochemicals, Indianapolis, IN) were used at concentrations of $1 \mathrm{mg} / \mathrm{ml}$ and $350 \mu \mathrm{g} / \mathrm{ml}$, respectively. Both reactions were incubated at $37^{\circ} \mathrm{C}$ for $30 \mathrm{~min}$, and the protease was then inactivated either by boiling the sample in a water bath for $5 \mathrm{~min}$ or by adding PMSF ( $1 \mathrm{mM}$ final concentration).

To determine whether $C$. michiganensis subsp. michiganensis secretes pectinases into the medium, we followed the method described by $\mathrm{He}$ et al. (27). Briefly, $5 \mu \mathrm{l}$ of culture was placed on the surface of A1 medium agar (2) that was supplemented with sodium polygalacturonate (Sigma Chemical Co.) at $0.4 \%$ final concentration. After $24 \mathrm{~h}$ at $28^{\circ} \mathrm{C}$, plates were flooded with a $1 \%$ cetyltrimethylammonium bromide solution. The formation of a clear area around the colony indicated the secretion of pectinases.

Partial purification of the HR-inducing activity. CFCS were prepared from CMM623 grown in YGM, and they were fractionated on a DEAE cellulose column (Whatman International, Ltd., Maidstone, England). This column was previously equilibrated with BT buffer (20 mM Bis-Tris, pH 6.0) (31). After the column had been washed with the same buffer, proteins were eluted with a $\mathrm{NaCl}$ step gradient $(100,200,300,500$, and 1,000 mM in BT buffer). Fractions were dialyzed against $50 \mathrm{mM}$ phosphate buffer, $\mathrm{pH}$ 7.0 , and used in plant reaction assays. Protein concentration was determined using the Bio-Rad protein assay kit (Bio-Rad Laboratories, Hercules, CA) with bovine serum albumin as the standard. CFCS proteins or the eluted fractions from the DEAE cellulose column were concentrated by trichloroacetic acid (TCA) precipitation (28) and separated by discontinuous $12.5 \%$ sodium dodecyl sulfate-polyacrylamide gel electrophoresis (SDS-PAGE). After electrophoresis, the gel was silver-stained (according to the Millipore In- vestigator TM 2-D electrophoresis system manual; Millipore Corp., Bedford, MA). A preparative gel containing CFCS proteins was cut into $0.5-\mathrm{cm}$ slices and the polypeptides were eluted, renatured (10), and used in HR assays.

To investigate the native molecular mass of the HR-inducing activity, CFCS were concentrated with a Centricon filter (Amicon, Beverly, MA) having a cut-off size of $3 \mathrm{kDa}$, and both the concentrate and pass-through material were used in infiltration assays. Also, CFCS were loaded onto a Sephacryl S-300 (Sigma Chemical Co. $)$ gel filtration column $(1.5 \times 50 \mathrm{~cm})$ previously equilibrated with $20 \mathrm{mM}$ Tris- $\mathrm{HCl}, \mathrm{pH} 8.0 ; 10 \mathrm{mM} \beta$-mercaptoethanol; and $1 \mathrm{mM}$ EDTA. One-milliliter fractions were collected and used immediately in infiltration assays.

\section{RESULTS}

Bacterial culture supernatants induce a HR. C. michiganensis subsp. michiganensis produced an apparent $\mathrm{HR}$ on $M$. jalapa when suspensions containing $5 \times 10^{8}$ colony forming units (CFU) per $\mathrm{ml}$ were infiltrated into the intercellular spaces of the leaves (Fig. 1A). Lower concentrations of bacteria, such as $10^{7} \mathrm{CFU} / \mathrm{ml}$, did not induce a visible necrosis in the plant after 6 days postinoculation. The distribution of the bacteria in planta remained limited to the infiltrated area, i.e., bacteria were not found after

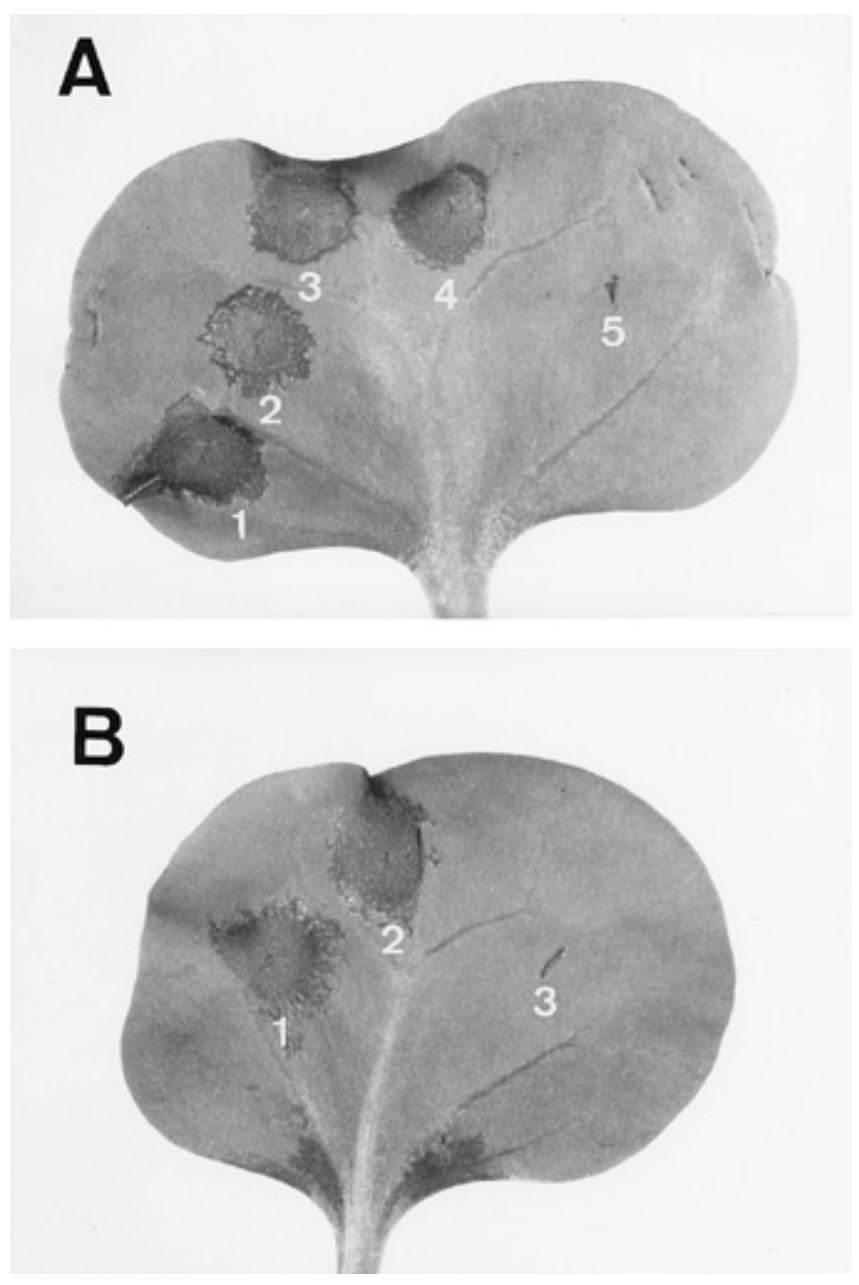

Fig. 1. Leaves of Mirabilis jalapa showing responses to bacteria and cellfree culture supernatants (CFCS). Leaves were infiltrated as described in Materials and Methods and photographed after $48 \mathrm{~h}$. A, $1=$ strain CMM623 at $5 \times 10^{8} \mathrm{CFU} / \mathrm{ml}, 2=\mathrm{CFCS}$ from CMM623 cells grown in M523 medium, $3=$ strain CMM100 at $5 \times 10^{8} \mathrm{CFU} / \mathrm{ml}, 4=\mathrm{CFCS}$ from CMM100 cells grown in M523 medium, and 5 = M523 medium. B, $1=$ CFCS from strain CMM623, 2 = heat-treated CFCS from strain CMM623, and $3=$ proteinase K-treated CFCS from strain CMM623. 
culturing stem sections of inoculated leaves. To determine whether C. michiganensis subsp. michiganensis produces a HR elicitor that is released outside the bacteria, we inoculated CFCS into $M$. jalapa. Figure 1A shows that CFCS induced a collapse of the infiltrated area that was similar to the response induced by bacteria. The tissue collapse was detected within $18 \mathrm{~h}$ after infiltration followed by a papery appearance after 3 to 4 days. The plasmid-free strain CMM100, as well as its CFCS, were also able to induce necrosis on $M$. jalapa leaves (Fig. 1A), showing that the CFCSinducing activity is determined by chromosomal genes. When inhibitors of active plant metabolism (cycloheximide, $\alpha$-amanitin, lanthanum chloride, and sodium vanadate) were infiltrated together with CFCS or bacteria, necrosis induction was prevented (data not shown). Inhibition of the HR in M. jalapa induced by bacteria or the HR in tobacco induced either by CFCS or bacteria was possible only when we used $5 \mathrm{mM}$ lanthanum chloride and $0.5 \mathrm{mM}$ sodium vanadate. These concentrations are fivefold and 10-fold higher, respectively, than those used by $\mathrm{He}$ et al. (25). Culture medium (M523 or YGM) did not induce any reaction in the plant (Fig. 1A). Similar results to those described here for $M$. jalapa were observed when bacteria and CFCS were infiltrated into tobacco leaves (data not shown).

Supernatant from a bacterial culture grown in minimal medium was also able to induce a HR on M. jalapa (data not shown).

The responsiveness of different plants to CFCS correlates with their response to live bacteria. Strain CMM623 and culture supernatants from the same bacterium were tested for biological activity by infiltration into the intercellular spaces of leaves in several different plant species. Among nine species of plants, strain CMM623 and its culture supernatants induced a HR only on $M$. jalapa and tobacco (Table 1). Therefore, there is agreement between the ability of the CFCS to induce a HR and the HR induced by strain CMM623 on the plants assayed. This result suggests that the elicitor activity found in the culture supernatant could be similar to, or the same as, the one produced by the bacteria in planta. More importantly, it suggests that the elicitor activity is not phytotoxic, but rather it provokes a specific response in the plant. It should be noted that CMM623 did not induce a HR on its natural host tomato, but instead it caused bacterial canker symptoms (data not shown). CFCS from Escherichia coli HB101 did not cause a reaction.

Characterization of the HR-inducing activity from CFCS. We have shown that CFCS prepared from strain CMM623 grown in minimal or M523 media induced a necrosis response on M. jalapa and tobacco. To investigate the chemical nature of the elicitor, different treatments of the CFCS were performed. Elicitor activity was active on $M$. jalapa after $10 \mathrm{~min}$ of heat treatment $\left(100^{\circ} \mathrm{C}\right)$ (Fig. 1B), although necrosis was induced only $40 \mathrm{~h}$ after infiltration and occasionally after 3 to 4 days. However, CFCS lost all HR-eliciting activity on $M$. jalapa when, prior to infiltration, they were digested with protease K (Fig. 1B) or Pronase for $30 \mathrm{~min}$ at $37^{\circ} \mathrm{C}$. Similar results were found when treated CFCS were assayed on tobacco (data not shown).

TABLE 1. Plant specificity of hypersensitive response induced by cell-free culture supernatants (CFCS) from strain CMM623

\begin{tabular}{lcc}
\hline & \multicolumn{2}{c}{ Necrosis reaction $^{\mathrm{a}}$} \\
\cline { 2 - 3 } Inoculated plant & $\begin{array}{c}\text { CMM623 cells } \\
\left(5 \times 10^{8} \text { CFU/ml) }\right.\end{array}$ & $\begin{array}{c}\text { CFCS from } \\
\text { CMM623 }\end{array}$ \\
\hline Mirabilis jalapa (four-o'clock) & + & + \\
Nicotiana tabacum (tobacco) & + & + \\
Lycopersicon esculentum (tomato) & - & - \\
Raphanus sativus (radish) & - & - \\
Capsicum annuum (pepper) & - & - \\
Brassica oleracea (cabbage) & - & - \\
Cucurbita pepo (squash) & - & - \\
Phlox sp. (phlox) & - & - \\
Apium graveolens (celery) & - & - \\
\hline
\end{tabular}

${ }^{\mathrm{a}}+$, necrotic response limited to infiltrated tissue; - , no response.
The proteinaceous elicitor is probably not a polygalacturonase enzyme, since we were not able to detect this enzyme activity in strain CMM623 (data not shown).

Partial purification of the elicitor. When CFCS were filtered through an Amicon filter (3,000 molecular weight exclusion), the concentrated material retained full elicitor activity, eliminating the possibility of low molecular weight elicitors such as syringolides (35). To determine the native size of the elicitor, we performed gel filtration chromatography on CFCS, and the column fractions were assessed for HR-inducing activity. The activity was consistently found in the 105-kDa molecular mass region (Fig. 2). HR-eliciting activity was also observed (although occasionally) migrating at molecular masses between 15 to $29 \mathrm{kDa}$ and $440 \mathrm{kDa}$ (Fig. 2). Similar results were observed in eight separate experiments.

To investigate whether the proteins from the sizing column were aggregates (misrepresenting the molecular mass), we separated CFCS proteins by SDS-PAGE. After elution, proteins were renatured and tested in plant reaction assays. Only those proteins in the molecular mass range of 35 to $50 \mathrm{kDa}$ and 12 to $16 \mathrm{kDa}$ had HR-inducing activity (Fig. 3). The same results were obtained in four separate experiments.

When CFCS were applied to a DEAE cellulose column, most of the elicitor activity eluted at $300 \mathrm{mM}$ and a residual activity was found in the $500 \mathrm{mM} \mathrm{NaCl}$-eluted material (Fig. 3). This elution profile is similar to that found for the proteinaceous C. michiganensis subsp. sepedonicus elicitor (31). The eluted material induced a necrotic response on $M$. jalapa and tobacco at a protein concentration as low as $7.3 \mu \mathrm{g} / \mathrm{ml}$.

\section{DISCUSSION}

In this study, we present evidence that $C$. michiganensis subsp. michiganensis produces at least one protein involved in the induction of a HR on M. jalapa and tobacco. This protein activity was found in the CFCS, suggesting it is secreted outside the bacterium.

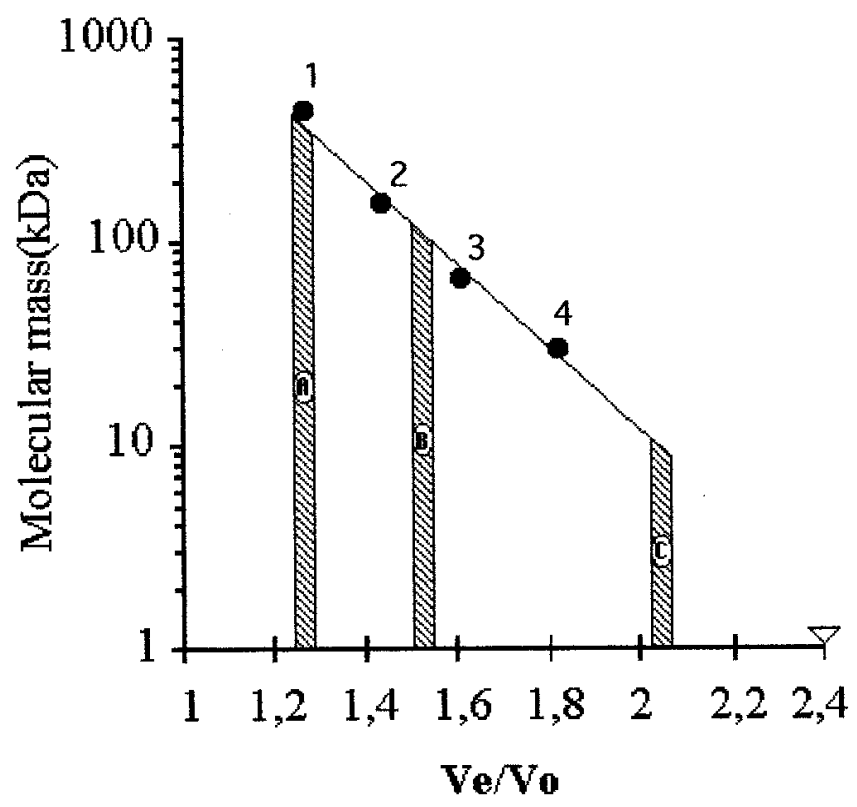

Fig. 2. Gel filtration chromatography of cell-free culture supernatants (CFCS) from strain CMM623. CFCS were loaded onto an S-300 Sephacryl column as described in Materials and Methods. Fractions were assayed for hypersensitive response, and those displaying necrosis-inducing activity on Mirabilis jalapa are indicated by shaded areas A, B, and C on the chromatogram. Open triangle indicates the elution of potassium ferricyanide, molecular mass 329.2 Da. Protein molecular weight markers (black circles; 443, 150,66 , and $29 \mathrm{kDa}$ ) were chromatographed under similar conditions as the sample, and protein absorbance was measured at $280 \mathrm{~nm}$. 
Bacterial pathogenicity factors (including elicitors) from gramnegative phytopathogenic bacteria are secreted by the specialized type III secretion encoded by the hrp genes that traverse both the cytoplasmic and outer membranes $(15,23,39)$. Although there is homology between flagellar Fla/Fli proteins of Bacillus subtilis and some Hrp proteins of $X$. campestris pv. campestris $(9,16)$, the absence of the outer membrane in gram-positive bacteria argues against a $h r p$ secretion system. It is possible that the protein described here uses a secretion system similar to the one that secretes the $80-\mathrm{kDa}$ pathogenicity factor internalin from Listeria monocytogenes $(18,19)$.

The necrosis-inducing protein described in this study and the elicitor protein recently described from $C$. michiganensis subsp. sepedonicus (31) share similar characteristics that include chromatographic behavior on DEAE cellulose, heat stability, and secretion to the culture supernatant. However, the elicitor from $C$. michiganensis subsp. sepedonicus induces a HR only on tobacco. Heat stability and secretion to the extracellular milieu are characteristics also shared by the gram-negative bacterial elicitor proteins harpin and PopA and some elicitors isolated from fungi $(5,24,33)$. These results are suggestive of a new family of proteins from gram-positive bacteria with necrosis-inducing activity in plants.

The reaction induced in $M$. jalapa by culture supernatants from C. michiganensis subsp. michiganensis seems to be a true HR, since it depends on active plant metabolism. The involvement of plant metabolic processes was demonstrated in the HR elicited by E. amylovora harpin (25) and more recently by the C. michiganensis subsp. sepedonicus elicitor (31).

When proteins from CFCS were separated by a SDS-PAGE, isolated, and used in biological assays, HR-eliciting activity was detected within the molecular mass range of 35 to $50 \mathrm{kDa}$. This result suggests that more than one protein with HR-eliciting ac-

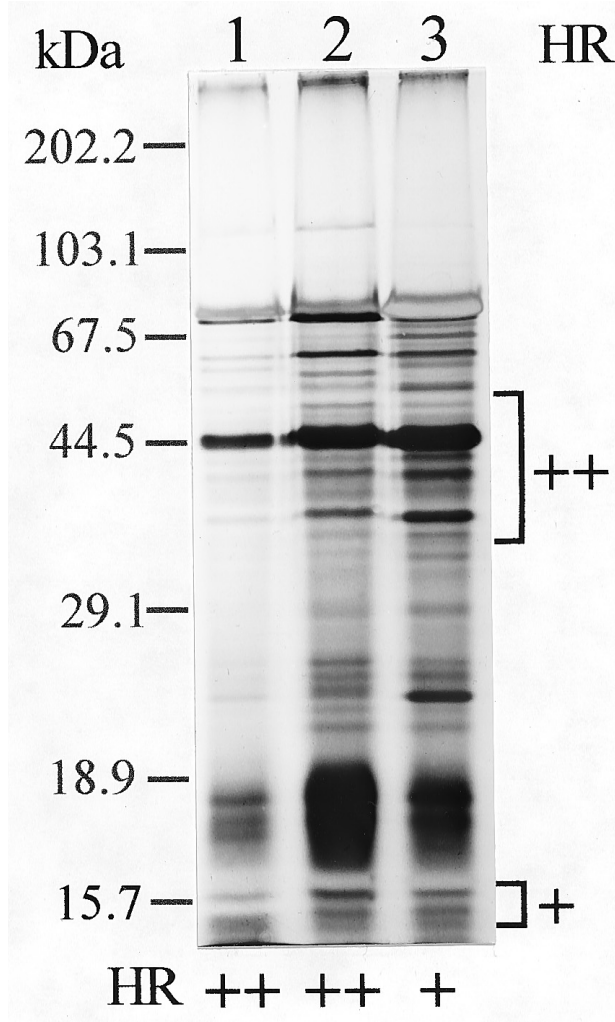

Fig. 3. Sodium dodecyl sulfate-12.5\% polyacrylamide gel electrophoresis of CMM623 proteins. Lane 1, cell-free culture supernatant proteins $(26 \mu \mathrm{g})$. Lanes $2(110 \mu \mathrm{g})$ and $3(100 \mu \mathrm{g})$, proteins eluting from DEAE at $300 \mathrm{mM}$ $\mathrm{NaCl}$ and $500 \mathrm{mM} \mathrm{NaCl}$, respectively. Proteins were stained with silver. ++, eluted proteins caused complete necrosis of the entire infiltrated area. +, eluted proteins caused partial necrosis of the infiltrated area. tivity is present. Alternatively, some activities and the weaker $15-\mathrm{kDa}$ activity could be due to degradation of a larger elicitor protein. Interestingly, PopA from $R$. solanacearum and the various harpins are similar in size (e.g., 28 to $44 \mathrm{kDa})(1,11,26,40)$ to the elicitor described here. Our SDS-PAGE results also argue against high molecular weight elicitors as those observed after gel filtration chromatography. In this respect, it has been reported that harpin from E. amylovora also aggregates during gel filtration, eluting at a much higher molecular mass than the monomer (40).

Recently, Bermpohl et al. (4) reported that the HR-inducing factor from C. michiganensis subsp. michiganensis is strictly associated with viable cells. In agreement, inoculation of $C$. michiganensis subsp. michiganensis at concentrations of $5 \times 10^{8} \mathrm{CFU} / \mathrm{ml}$ in the presence of $50 \mu \mathrm{g}$ of rifampicin or streptomycin per $\mathrm{ml}$ (bacterial protein synthesis inhibitor) did not induce a response in $M$. jalapa (data not shown). This suggests that, in planta, the elicitor needs to be produced by the bacteria and is not a preformed structural part of it. Surprisingly, Bermpohl (4) also reported that sterile filtrates from culture supernatants of strain NCPPB382 did not induce a HR on M. jalapa. In our hands, supernatants of the same strain did induce a response on $M$. jalapa, although this response was delayed and weaker compared with supernatants from strain CMM623. In addition, culture supernatants from the endophyte CMM100 (plasmid-free derivative of the pathogenic strain NCPPB382), also induced a necrotic response on $M$. jalapa, indicating the chromosomal location of the genes determining this activity. The conflicting results observed between Bermpohl (4) and us could be due to the age of the cultures. They used overnight cultures (there is no information about the growth phase of the bacteria), instead we used stationary phase or older cultures. HR-inducing activity was detected only in supernatants from cultures in or after the late log phase (data not shown). The different results could also be due to differences in host physiology, since we usually observed negative results with plants that had been grown at low temperatures $(0$ to $20^{\circ} \mathrm{C}$ ). These cold-raised plants have succulent leaves and most of them have a red pigmentation in the stem.

The results of this study are significant, because they report a new class of proteins with HR-inducing activity in gram-positive bacteria and open important prospects for investigating secretion machinery in gram-positive bacteria.

\section{ACKNOWLEDGMENTS}

We thank G. Mora L., A. Venegas, and H. Thieringer for critical reading of the manuscript.

\section{LITERATURE CITED}

1. Arlat, M., Van Gijsegem, F., Huet, J. C., Pernollet, J. C., and Boucher, C. A. 1994. PopA1, a protein which induces a hypersensitivity-like response on specific Petunia genotypes, is secreted via the Hrp pathway of Pseudomonas solanacearum. EMBO (Eur. Mol. Biol. Organ.) J. 13:543-553.

2. Ausubel, F. M., Brent, R., Kingston, R., Moore, D., Seidman, J. G., Smith, J. A., and Struhl, K. 1992. Short Protocols in Molecular Biology. John Wiley \& Sons, New York.

3. Bauer, D. W., Bogdanove, A. J., Beer, S. V., and Collmer, A. 1994. Erwinia chrysanthemi hrp genes and their involvement in soft rot pathogenesis and elicitation of the hypersensitive response. Mol. Plant-Microbe Interact. 7:573-581.

4. Bermpohl, A., Dreier, J., Bahro, R., and Eichenlaub, R. 1996. Exopolysaccharides in the pathogenic interaction of Clavibacter michiganensis subsp. michiganensis with tomato plants. Microb. Res. 151:391-399.

5. Billard, V., Bruneteau, M., Bonnet, P., Ricci, P., Pernollet, J. C., Huet, J. C., Vergne, A., Richard, G., and Michel, G. 1988. Chromatic purification and characterization of elicitors of necrosis on tobacco produced by incompatible Phytophthora species. J. Chromatogr. 44:87-94.

6. Bogdavone, A. J., Wei, Z.-M., Zhao, L., and Beer, S. V. 1996. Erwinia amylovora secretes harpin via a type III pathway and contains a homolog of yopN of Yersinia spp. J. Bacteriol. 178:1720-1730.

7. Bonas, U. 1994. hrp genes of phytopathogenic bacteria. Pages 79-98 in: Current Topics in Microbiology and Immunology. Vol. 192. Bacterial Pathogenesis of Plants and Animals: Molecular and Cellular Mecha- 
nisms. J. L. Dangl, ed. Springer-Verlag, Berlin.

8. Bonas, U., and Van den Ackerveken, G. 1997. Recognition of bacterial avirulence proteins occurs inside the plant cell: A general phenomenon in resistance to bacterial diseases? Plant J. 12:1-7.

9. Carpenter, P. B., Zuberi, A. R., and Ordal, G. W. 1993. Bacillus subtilis flagellar protein FliP, FliQ, FliR and FlhB are related to Shigella flexneri virulence factors. Gene 137:243-245.

10. Cortes, P., Buckbinder, L., Leza, M. A., Rak, N., Hearing, P., Merino, A., and Reinberg, D. 1988. EivF, a factor required for transcription of the adenovirus EIV promoter, binds to an element involved in EIa-dependent activation and cAMP induction. Genes Dev. 8:975-990.

11. Cui, Y., Madi, L., Mukherjee, A., Dumenyo, C. K., and Chatterjee, A. K. 1996. The RsmA- mutants of Erwinia carotovora subsp. carotovora strain Ecc71 overexpress $h r p N_{E c c}$ and elicit a hypersensitive reactionlike response in tobacco leaves. Mol. Plant-Microbe Interact. 9:565-573.

12. De Boer, S. H., Van Vaerenbergh, J., Stead, D. E., Janse, J. D., and McKenzie, A. R. 1992. A comparative study in five laboratories on detection of Clavibacter michiganensis subsp. sepedonicus in potato stems and tubers. Potato Res. 35:217-226.

13. Dixon, R. A., and Lamb, C. J. 1990. Molecular communication in interactions between plants and microbial pathogens. Annu. Rev. Plant Physiol. Plant Mol. Biol. 41:339-367.

14. Fatmi, M., and Schaad, N. W. 1988. Semiselective agar medium for isolation of Clavibacter michiganense subsp. michiganense from tomato seed. Phytopathology 78:121-126.

15. Fenselau, S., Balbo, I., and Bonas, U. 1992. Determinants of pathogenicity in Xanthomonas campestris pv. vesicatoria are related to proteins involved in secretion in bacterial pathogens of animals. Mol. PlantMicrobe Interact. 5:390-396.

16. Fenselau, S., and Bonas, U. 1995. Sequence and expression analysis of the hrpB pathogenicity operon of Xanthomonas campestris pv. vesicatoria which encodes eight proteins with similarity to components of the Hrp, Ysc, Spa, and Fli secretion systems. Mol. Plant-Microbe Interact. 8:845-854.

17. Flor, H. H. 1942. Inheritance of pathogenicity in Melampsora lini. Phytopathology 32:653-669.

18. Gaillard, J.-L., Berche, P., Frehel, C., Gouin, E., and Cossart, P. 1991. Entry of L. monocytogenes into cells is mediated by internalin, a repeat protein reminiscent of surface antigens from gram-positive cocci. Cell 65:1127-1141.

19. Gallagher, R. B. 1996. Enter Listeria, unruffled. Science 271:1825.

20. Gitaitis, R. D. 1990. Induction of a hypersensitivelike reaction in fouro'clock by Clavibacter michiganensis subsp. michiganensis. Plant Dis. 74:58-60.

21. Goodman, R. N., and Novacky, A. 1994. The hypersensitive reaction in plants to pathogens. A resistance phenomenon. The American Phytopathological Society, St. Paul, MN.

22. Gopalan, S., Bauer, D., Alfano, J., Loniello, A. O., He, S. Y., and Collmer, A. 1996. Expression of the Pseudomonas syringae avirulence protein AvrB in plant cells alleviates its dependence on the hypersensitive response and pathogenicity (Hrp) secretion system in eliciting genotype-specific hypersensitive cell death. Plant Cell 8:1095-1105.

23. Gopalan, S., and He, S. Y. 1996. Bacterial genes involved in the elicitation of hypersensitive response and pathogenesis. Plant. Dis. 80:604-610.

24. Hahn, M. G. 1996. Microbial elicitors and their receptors in plants. Annu. Rev. Phytopathol. 34:387-412.

25. He, S. Y., Bauer, D. W., Collmer, A., and Beer, S. V. 1994. Hypersensi- tive response elicited by Erwinia amylovora harpin requires active plant metabolism. Mol. Plant-Microbe Interact. 7:289-292.

26. He, S. Y., Huang, H. C., and Collmer, A. 1993. Pseudomonas syringae pv. syringae harpin ${ }_{\mathrm{Pss}}$ : A protein that is secreted via the hrp pathway and elicits the hypersensitive response in plants. Cell 73:1255-1266.

27. He, S. Y., Lindeberg, M., Chatterjee, A. K., and Collmer, A. 1991 Cloned Erwinia chrysanthemi out genes enable Escherichia coli to selectively secrete a diverse family of heterologous proteins to its milieu. Proc. Natl. Acad. Sci. U.S.A. 88:1079-1083.

28. Kaniga, K., Trollinger, D., and Galán, J. E. 1995. Identification of two targets of the type III protein secretion system encoded by the inv and spa loci of Salmonella typhimurium that have homology to the Shigella IpaD and IpaA proteins. J. Bacteriol. 177:7078-7085.

29. Klement, Z. 1982. Hypersensitivity. Pages 149-177 in: Phytopathogenic Prokaryotes. M. S. Mount and G. H. Lacy, eds. Academic Press, New York.

30. Meletzus, D., and Eichenlaub, R. 1991. Transformation of the phytopathogenic bacterium Clavibacter michiganense subsp. michiganense by electroporation and development of a cloning vector. J. Bacteriol. 173: 184-190.

31. Nissinen, R., Lai, F.-M., Laine, M. J., Bauer, P. J., Reilley, A. A., Li, X., De Boer, S. H., Ishimaru, C. A., and Metzler, M. C. 1997. Clavibacter michiganensis subsp. sepedonicus elicits a hypersensitive response in tobacco and secretes hypersensitive response-inducing protein(s). Phytopathology 87:678-684.

32. Parker, J. E., and Coleman, M. J. 1997. Molecular intimacy between proteins specifying plant-pathogen recognition. Trends Biochem. Sci. 22:291-296.

33. Parker, J. E., Schulte, W., Hahlbrock, K., and Scheel, D. 1991. An extracellular glycoprotein from Phytophthora megasperma f. sp. glycinea elicits phytoalexin synthesis in cultured parsley cells and protoplasts. Mol. Plant-Microbe Interact. 4:19-27.

34. Scofield, S. R., Tobias, C. M., Rathjen, J. P., Chang, J. H., Lavalle, D. T., Michelmore, R. W., and Staskawicz, B. J. 1996. Molecular basis of genefor-gene specificity in bacterial speck disease of tomato. Science 274: 2063-2065.

35. Smith, M. J., Mazzola, E. P., Sims, J. J., Midland, S. L., Keen, N. T., Burton, V., and Stayton, M. M. 1993. The syringolides: Bacterial C-glycosyl lipids that trigger plant disease resistance. Tetrahedron Lett. 34: 223-226.

36. Staskawicz, B. J., Ausubel, F. M., Baker, B. J., Ellis, J. G., and Jones, J. D. 1995. Molecular genetics of plant disease resistance. Science 268: 661-667.

37. Tang, X., Frederick, R. D., Zhou, J., Halterman, D. A., Jia, Y. M., and Martin, G. B. 1996. Initiation of plant resistance by physical interaction of AvrPto and Pto kinase. Science 274:2060-2063.

38. Van den Ackerveken, G., Marois, E., and Bonas, U. 1996. Recognition of the bacterial avirulence protein AvrBs3 occurs inside the host plant cell. Cell 87:1307-1316.

39. Van Gijsegem, F., Genin, S., and Boucher, C. A. 1993. Conservation of secretion pathways for pathogenicity determinants of plant and animal bacteria. Trends Microbiol. 1:175-180.

40. Wei, Z.-M., Laby, R. J., Zumoff, C. H., Bauer, D. W., He, S. Y., Collmer, A., and Beer, S. V. 1992. Harpin, elicitor of the hypersensitive response produced by the plant pathogen Erwinia amylovora. Science 257:85-88.

41. Yang, Y., Shah, J., and Klessig, D. F. 1997. Signal perception and transduction in plant defense responses. Genes Dev. 11:1621-1639. 